\title{
ADORACJA MATKI BOSKIEJ W ASYŚCIE DWÓCH ŚWIĘTYCH JANÓW W ZBIORACH KATEDRY WAWELSKIEJ
}

W katedrze na Wawelı znajduje się obraz na plótnie, w kształcie wydłużonego prostokata o półkolistych zakończeniach z kwadratowymi wykrojami w narożnikach, formatem zbliżony do predelli (il. 1-3). Izolowane dzieło, nie związane z żadnym $z$ istniejących ołtarzy, nie występuje w inwentarzach i nie ma - jak dotąd potwierdzonej katedralnej metryki ${ }^{1}$. Jego obecność w świątyni może łączyć się z akcją gromadzenia zabytków sakralnych podjętą około roku 1900 , z myślą o utworzeniu w Krakowie Muzeum Diecezjalnego. Wobec milczenia źródeł domniemana proweniencja spoza katedry, z szeroko pojętego terenu Małopolski, wydaje się bardziej prawdopodobna niż odłączenie malowidła od któregoś z wawelskich ołtarzy.

Scena, zakomponowana w poziomie ${ }^{2}$, wypełnia płaszczyznę o wymiarach 98,5 x 222,5 cm. Pośrodku, na tronie, pod baldachimem zredukowanym do lambrekinu biegnącego wzdłuż gómej krawędzi obrazu, siedzi Maria z Dzieciątkiem. Towarzyszą Jej święci - Jan Chrzciciel (z lewej), kornie schylony ku małemu Zbawicielowi i Jan Ewangelista ( $\mathrm{z}$ prawej), odwrócony w kierunku widza, z kielichem i błogosławiącym gestem lewej dłoni. $\mathrm{Na}$ pierwszym planie klęczą dwa adorujące anioły w strojach diakonów, $z$ kadzielnicami w rękach. Dym z kadzideł ściele się u stóp Marii. Diagonalne linie, wyznaczone przez ich pozy, zbiegające się w centrum układu, symetria całej kompozycji - służą podkreśleniu figur na osi obrazu. Scenę ujmują kulisowo dwie wielkie podwieszone kotary, ogromnymi festonami opadające po bokach. Oliwkowozielony aksamit, ze złocistymi blikami na grzbietach fałdów, kontrastuje z lokalną czerwienią płaszczy obu świętych Janów. Brązowozłoty, wielkowzorzysty zaplecek tronu stanowi tło dla postaci Marii, odzianej w suknię w kolorze kraplakowego różu i ciemnoniebieski płaszcz. Na jej włosach spoczywa mała, otwarta korona sadzona kamieniami; głowę otacza promienista aureola (il. 2). Jezus, błogosławiący lewą ręka, w prawej trzyma nagą kolczastą gałąź - cierniowe berło (il. 3). Bogurodzica - także w prawej dłoni - dzierży gałązkę oliwną. Schylone nisko, klęczące anioły w zlotych dalmatykach i białych albach oddają cześć Matce

Katalog zabytków sztuki w Polsce, IV, Miasto Kraków, 1, Wawel, red. J. Szablowski, Warszawa 1965, s. 10I, il. 386. Obecnie eksponowany w Muzeum Katedralnym.

${ }^{2}$ Olej, płótno; rozpięty na nowym krośnie, dublowany na nowym fabrycznym płótnie. Konserwowany zapewne po roku 1960, za kadencji Rudolfa Kozłowskiego (1908-1977), w latach 1947-1977 głównego konserwatora zabytków na Wawelu. Oryginalne płótno zszyte poziomo z dwóch części (szerokość brytu $80 \mathrm{~cm}$ ). Warstwa malarska dobrze zachowana, z niewielkimi retuszami. Mechaniczne przebicie płótna pośrodku głowy prawego anioła. 
Boskiej i Dzieciątku. Zwrócone tyłem do widza, usytuowane na proscenium obrazu, tworzą tu teatralny, pogłębiający przestrzeń pierwszy plan.

Sprawny rysunek fizjonomii, rąk, akcesoriów, umiejętne operowanie światłem padającym z lewej strony, charakterystyczne budowanie bryły i traktowanie karnacji składają się na dzieło o stricte manierystycznej wymowie, przynależące do środkowoeuropejskiej (najpewniej polskiej) spuścizny malarskiej pierwszych dekad wieku XVII. Całość prezentuje dobry poziom i wytrawne rzemiosło. Namacalny wolumen postaci i ciemnoszare podmalowanie karnacji o powierzchniach wydobytych transparentnymi, ,podświetlonymi" bielami i różami - zbliżają manierę rodzimego artysty do warsztatu niderlandzkich i południowoniemieckich mistrzów z lat około 1600 - Hendricka de Clerck, Johanna Rottenhammera, Petera Candida czy Hansa von Aachen. Rysy twarzy i modelunek fałdów szat podkreśla delikatny, wrażliwy kontur, który nadaje formom właściwą północnym szkołom wyraźną artykulację.

Wrażenie obcowania $z$ dziełem o niderlandzkim bądź niemieckim rodowodzie potwierdza wzór graficzny, który udało się odnaleźć. Jest to miedzioryt Jana Sadelera (1550-1600), według Hansa von Aachen (1552-1615), wydany w Monachium w r. 1589 (il. 4) ${ }^{3}$. Zachowal się rysunek do niego, tych samych rozmiarów co plansza $\left(22,6\right.$ x 32,9 cm) w zbiorach wiedeńskiej Albertiny (il. 5) ${ }^{4}$ oraz szkic koncepcyjny, pierwsza inwencja tego przedstawienia, w Herzog Anton Ulrich-Museum w Brunszwiku (ten ostatni - na odwrocie przerysu zaginionej kompozycji Jodocusa a Winghe (1544-1603), poświęconej wyzwoleniu Belgii ${ }^{5}$.

Nietrudno wykryć różnice między rysunkową i graficzną wersją kompozycji. Poza oczywistą zamianą kierunków, w szkicu z Albertiny widzimy inaczej uniesione skrzydła aniołów, podest pod tronem Matki Boskiej, luźno opadające zasłony, bardziej frontalną pozycję Dzieciątka. Wkład Jana Sadelera zdecydował o ostatecznym kształcie planszy. Artysta nie tylko dopowiedział szczególy, wnosząc do charakterystyki głów elementy portretowe (sugestia, iż św. Jana Chrzciciela obdarzył rysami Albrechta Dürera, ma wiele cech prawdopodobieństwa) ${ }^{6}$. Wzbogacił realia kostiumowe i rzeczowe, konkretyzując tlo i wzory na tkaninach; wprowadził też szereg napisów, które nadały dziełu określony program. Inskrypcja: POENA ET PROEMIVM, na zaplecku ponad głową Marii, ma bardzo ogólny wydźwięk, tak iż mogłaby dotyczyć eschatologicznego przesłania obrazu - idei Odkupienia uwarunkowanej przez wcielenie Chrystusa. Natomiast banderole u stóp aniołów z wersetami psalmów: Victima grata Deo mens attenuata: cor ae-

${ }^{3}$ Miedzioryt, 23,7 x 33,3 cm; sygn. i dat. - A. von Wü r z b a c h, Niederländisches Künstler-Lexikon, II, Wien-Leipzig 1910, s. 539, poz. 56 (jako wg Jodocusa a Winghe); F. W.

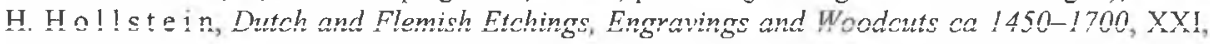
Amsterdam 1980, s. 130, poz. 287; Das gestachene Bild. Von der Zeichnung zum Kupferstich, Herzog Anton Uirich-Museum, Braunschweig 1987, s. 29-30, poz. 13.

${ }^{4}$ Rys. piórkiem, lawowany; 22,6 x 32,9 cm; sygn. Hans Vonach; nr inw. $26359-\mathrm{H}$. Tietze und E. T i etze-Conrat, O. Benesch, K. Garzarolli-Thurnlackh, Die Zeichnungen der deutschen Schulen bis zum Beginn des Klassizismus. Beschreibender Katalog der Handzeichnungen in der Graphischen Sammlung Albertina, IV-V, Wien 1933, I, s. 55, poz. 439; II, i1. 439; Das gestochene Bild 1987, s. 28-29, poz. 12.

${ }^{5}$ Piórko, sepia; $17,5 \times 23 \mathrm{~cm}$; nr inw. Z. 533rs. Paroma kreskami zaznaczony schemat kompozycji z autorskimi napisami: Joan evangelis oraz Joan daper - Das gestochene Bild 1987, s. 28, poz. 11 .

${ }^{6}$ Das gestochene Bild 1987, s. 29. 
gro / Deiectum in luctu suscipis, alme Deus. Ex Psal: LI (z lewej) oraz Tu procul omne meum scelus hinc mortumque fugasti: / Te Deus assidua vox mea laude canet. Ex Psal: CII (z prawej) ${ }^{8}$ - sławią pokore serca, cnotę skromności i ufność w pomoc Bożą. Wiele wyjaśnia dedykacja, w której rytownik umieścił swą sygnaturę i datę: ILLVSTRISSIMO ET REVERENDISSIMO PRINCIPI. AC DNO. DE. PHILIPPO. EPISCOPO RATISPONENSI. DVCI B: et / Sereniss. Gvilhelmi Comitis Palatini Rheni et vtrivsq ${ }_{3}$ Bavariae Dvcis filio etc. / Joan. Sadl. autor et sculpt. D. D. 1589. W prawym dolnym rogu, na posadzce widnieje napis: Ioan von Achen figura: Adresatem ryciny był Filip Wilhelm (1576-1598) Wittelsbach, syn Wilhelma V Bawarskiego (1548-1626), w tymże roku, w wieku lat trzynastu, mianowany biskupem Ratyzbony, później (1596) - kardynałem². Rok 1589 oznaczał jeszcze jeden punkt zwrotny w karierze księcia: został on wówczas wybrany na rektora Uniwersytetu w Ingolstadt (18 X 1589), a w końcu zimowego semestru (1589/90) musiał uroczyście złożyć ten urząd ${ }^{10}$. Pytanie, czy sentencja POENA ET PROEMIVM mogłaby być aluzją do jego degradacji i wywyższenia - pozostaje nie rozstrzygnięte. Młodociany hierarcha otrzymał w darze w tej planszy kompozycję opatrzoną tekstami odnoszącymi się do jego formacji duchowej i jej doskonalenia. Piękna sadelerowska Madonna w centrum sceny przekształciła się tu jakby w Patronkę Bawarii, Opiekunkę kraju i dynastii ${ }^{11}$.

Do takiej konstatacji skłania następna rycina tego samego twórcy, według Petera Candida (1548-1628), poświęcona Ferdynandowi $(1577-1650)^{12}$, młodszemu synowi Wilhelma Bawarskiego, datowana $1590^{13}$. Dostał ją kolejny książę z panującej rodziny, także od dziecka przeznaczony do stanu duchownego, wcześnie wchodzący w dorosłe życie. (Drogi życiowe obu chłopców wytyczono w myśl planów politycznych ich ojca, który postanowił w ten sposób wzmocnić kościół katolicki

${ }^{7}$ Tekst jest nawiązaniem do Psalmu 50(51), werset 19, w dosłownym przekładzie brzmi: „Miłą Bogu ofiarą jest umysł skromny, popadłe w zgryzoty serce, z rozpaczy podnosisz dobrotliwy Boże" - por. Bibliorum Sanctorum iuxta Vugatam critice editum, quas digessit Bonifatius Fischer OSB, Stuttgart-Bad Cannstatt 1977, s. 832. Werset ten w przekładzie J. Kochanowskiego: Ofiara przyjemna Bogu - duch strapiony / serce uniżone, umysl ukorzony - J. K o c h a n o w s k i, Dzieła polskie, I, oprac. J. Krzyżanowski, Warszawa 1967, s. 399.

${ }^{8}$ Cytat, jak i poprzedni, jest parafrazą Psalmu 102(103), wersetów 1-3, 12, w dosłownym przekładzie brzmi: $W$ dal odegnateś me nieszczęście i chorobę, Twa, Boze, chwate nieustajaco głos mój śpiewa. Za tłumaczenie i konsultację składam podziękowanie dr. Markowi Janickiemu.

${ }^{9}$ Por:: Rom und Bayern. Kunst und Spiritualität der ersten Jesuiten, Bayerisches Nationalmuseum, red. R. Baumstark, München 1997, s. 338-340, 372-373, poz. 44-46, 74.

${ }^{10}$ Obie ceremonie utrwalono w dwóch gwaszach (C. Freisingera?) w Metryce Uniwersytetu, 1589/1590 - Rom und Bayern 1997, s. 338-340, poz. 45.

1 Tronująca Matka Boska z Dzieciątkiem, jako Patrona Bavariae, została ogłoszona Opiekunką i symbolem tożsamości tego kraju w czasach kontrreformacji. Posagi i ryciny, medale i monety szerzyły jej kult do końca w. XVIII.

${ }^{12}$ Biographisch-Bibliographisches Kirchenlexikon, XXI, Hamburg 2003, szp. 87-90 (oprac. R. Baier).

${ }^{13}$ Miedzioryt; 23,7 x 22,4 cm; napisy - u góry baldachimu: VITA ET LVX HOMINVM; na zaplecku tronu: Lumine ... splendet Pro. 4; poniżej: Qvonia ... occisionis. Dedykacja: SERENISSIMO PRINCIPI DE. DNO FERDINANDO DVCI B SEREN GVILLELMI COMIT PALAT RHENI ET VTRIVSQ ${ }_{3}$ BAVARIAE DVCI FILIO etc. Joan Sadeler autor et sculptor 1590. Na ruszcie św. Wawrzyńca w prawym dolnym rogu: Peter Candid figuravit - Würzbach 1910, s. 539, oz. 50 (jako wg Jodocusa a Winghe); U. Thieme, F. Becker, Allgemeines Lexikon der Bildenden Künstler, XXIX, Leipzig 1935, s. 300 (już z atrybucją P. Candidowi); Hollstein 1980, s. 131, poz. 289. 
w Bawarii). Podobna do poprzedniej adoracja tronujacej Marii z Dzieciątkiem, z udziałem świętych Stefana i Wawrzyńca, ma równie budująca wymowę. Wymiary rycin są identyczne, napisy dedykacyjne tak samo sformułowane, nie ulega więc wątpliwości, że stanowią one pendant. Obydwie grafiki przypadają na okres wspólnej aktywności Hansa von Aachen i Jana Sadelera w służbie Wilhelma V na dworze monachijskim, tj. lata $1589-1595^{14}$, i komentują w pewien sposób posunięcia dynastyczne władcy.

Krakowski obraz pomija cytaty psalmiczne i wszelkie inne napisy, koncentrując się na samych uczestnikach sceny. Stąd prawdopodobny byłby jego związek $\mathrm{z}$ patrocinium ołtarza świętych Janów ${ }^{15}$. Mimo tradycyjnie przydawanego mu miana predelli nasuwa się inna możliwość umiejscowienia go w strukturze ołtarzowej - w zwieńczeniu głównej części retabulum. Takie rozwiązania spotykamy w XVII-wiecznych ołtarzach na terenie Małopolski ${ }^{16}$.

Stylistycznie porównać można Marię z naszej Adoracji z wizerunkami pędzla artystów pokolenia Hermana Hana i Bartłomieja Strobla, choć są to oczywiste zbieżności konwencji, a nie warsztatu. Odstępstwa od ryciny (m.in. korona na głowie Matki Boskiej) oraz sama materia malarska (pierwotna, mimo drobnych interwencji konserwatorskich) zbliżają to przedstawienie do dzieł krakowskiego środowiska z pierwszej tercji w. XVII, z reguły zresztą słabszych artystycznie. Wskazanie dlań bliższych analogii wymaga szerszej kwerendy i musi poczekać na inną okazję.

W polskich zbiorach ujawniono jeszcze jedną malarską wersje grafiki Sadelera - niewielki obraz na desce, z prywatnej kolekcji wielkopolskiej (il. 6) ${ }^{17}$. O ile wolno sądzić z fotografii - to dobrej klasy dzieło idzie dość wiernie za rycina, zwłaszcza w charakterystyce głów i powtórzeniu napisów. Nie jest przy tym ro-

${ }^{14}$ Kariery obydwu mialy przebieg międzynarodowy. Von Aachen pracował weześniej we Frankfurcie i Augsburgu, od 1589 r. na dworze Wittelsbachów w Monachium, po 1592 r. - dla Rudolfa II w Pradze. Jan I Sadeler, urodzony i czynny w Antwerpii, w 1588 powołany został przez Wilhelma V do Bawarii, gdzie działał do 1595 r. Obaj uprawiali sztukę w służbie propagandy religijnej i politycznej władcy - E. F u č i k o vá, Über die Tätigkeit Hans von Aachens in Bayern, „Münchner Jahrbuch der bildenden Kunst”, 3. Folge, XXI(1970), s. 129-142, zwłaszcza 131-138. $\mathrm{O}$ artystach por: $\mathrm{R}$. A. P eltzer, Der Hofmaler Hans von Aachen - seine Schule und seine Zeit, ,Jahrbuch der Kunsthistorischen Sammlungen des Allerhöchsten Kaiserhauses”, XXX(1911-1912), s. 59-182; J. de R a ma ix, Les Sadeler: de damasquineur à graveur et marchand d'estampes. Quelques documents inédits, „Livre et l'estampe”, XXXV(1989), nr 131, s. 7-46; Una dinastia di incisori: I Sadeler, red. C. Limentani Viridis, F. Pellegrini, G. Piccin, Padova 1992.

${ }^{15}$ W katedrze wawelskiej istnieją do dziś wezwania kaplic: św. Jana Chrzciciela (bp. Zadzika) oraz św. Jana Ewangelisty (bp. Załuskiego). W Krakowie patrocinium Św. Janów wiąże się z kościołem Prezentek (KZSP, IV, Miasto Kraków, II, Kościoły i klasztory Śródmieścia, 1, red. A. Bochnak, I. Samek, W/arszawa 1971, s. 114 149), w średniowieczu tylko św Jana Chrzciciela - J. Rajman, Sredniowieczne patrocinia krakowskie, Kraków 2002, s. 73. W dawnym powiecie olkuskim to podwójne wezwanie nosi m. in. kościół par. w Pilicy (KZSP, I, Województwo krakowskie, z. 12, powiat olkuski, oprac. K. Kutrzebianka, Warszawa 1953, s. 23-26). Niewykluczone, iż wymiana ołtarzy w XVIII wieku w którymkolwiek z kościołów Małopolski mogła spowodować wyjęcie z poprzedniej struktury ,patronalnego" obrazu.

${ }^{16} \mathrm{M}$.in. prawie identyczny wykrój posiada obraz w górnej kondygnacji ołtarza głównego w Chełmcach - KZSP, III, Województwo kieleckie, z. 4, Powiat kielecki, oprac. J. Z. Łoziński, B. Wolff, Warszawa 1957 , s. 12, il. 56.

${ }^{17}$ Tempera i olej, drewno, $52,2 \times 66 \mathrm{~cm}$, na podobraziu z dwóch desek. Na odwrociu napis: Fra Bartolomeo. Dziękuję panu Jerzemu Żmudzińskiemu za informację i udostępnienie fotografii obrazu. 
dzimą transpozycją importowanego modelu, ale być może realizacją zachodnioeuropejską (śląską ?), bardzo bliską pierwowzonu. Same fizjonomie dokładnie naśladują twarze uksztaltowane przez Sadelera, światłocień i walory wydają się tu pogłębione i nasycone, a traktowanie całości ma więcej pierwiastka malarskiego niż graficznego, tracąc przez to charakter odtwórczy.

Rola europejskiej produkcji graficznej w kształtowaniu oblicza polskiego malarstwa końca XVI i pierwszej połowy XVII wieku zaprzątała już uwagę wielu. badaczy $^{18}$. Problem zależności od rycin dotyczy również sztuki przodujących obszarów Europy Zachodniej, nie tylko receptywnych z pozoru środkowowschodnich jej terenów bądź obrzeży.

W zjawisku, jakim jest odbiór wzorów graficznych w Polsce w okresie manieryzmu, trudno wykryć jakieś prawidłowości. Nikt dotąd nie podjął prób nakreślenia mapy rozpowszechnienia grafiki, a nawet głównych linii jej napływu z wiodących europejskich ośrodków. Przedsięwzięcie takie wydaje się skazane na niepowodzenie wobec mało uchwytnego materiału, ruchliwości twórców i pośredników, krzyżowego zapotrzebowania pracowni malarskich i uprawiających rzemiosło artystyczne, które powodowało ogromną koniunkturę na sprowadzanie łatwo mobilnych plansz. Prym w tym zakresie wiodła przemożna produkcja oficyn niderlandzkich. Jednak, przy stosunkowo słabym wówczas przyswajaniu grafiki francuskiej i nie tak wielkiej konsumpcji rycin włoskich (trzeba pamiętać, że inwencje włoskie sztychowali i wydawali także Flamandowie i Niemcy) - krag wzorów graficznych $z$ rodowodem bawarskim i praskim zdaje się osiagać w środowisku krakowskim dominująca pozycje. Dobrym tego przykładem jest, oparty na monachijskiej planszy, obraz wawelski.

Za panowania Zygmunta III Wazy naturalne kontakty z Rzeszą oraz dworem i domem Wittelsbachów wzmacniały wymianę rzemieślników i przepływ zamówień na południe Niemiec, przede wszystkim do Augsburga ${ }^{19}$. Niewykluczone, że recepcja rycin z Bawarii towarzyszyła zlecenion złotniczym i ożywieniu artystycznemu na linii Kraków - Monachium - Augsburg. Nie jest to generalnie odpowiedź na pytanie o złożone pochodzenie impulsów i wzorców polskiego malarstwa doby manieryzmu, ale ocena efektów w postaci choćby niekompletnie zachowanych dziel, pozwoliłaby może na obserwacje frekwencyjne, a w przyszłości - na konkretne podsumowania.

${ }^{18}$ Tytułem przykładu można wymienić prace: A. Gosieniecka, Wzory graficzne w malarstwie potowy XVI i poczatku XVII wieku. Ze studiów nad sztukq XVI w. na Slasku $i$ w krajach sasiednich, Wrocław 1968; M. M a ch ar ska, Rola grafiki w twórczości Tomasza Dolabelli, „Folia Historiae Artium”, IX (1973), s. 89-126; M. M a c h a r s k a, Ze studiów nad rola grafiki w polskim malarstwie okresu manieryzmu i wczesnego baroku (Obrazy w kościolach Wielkopolski oraz w kolegiacie towickiej), „Folia Historiae Artium” XI(1975), s. 139-165; J. D zik, Franciszek Lekszycki, malarz religijny baroku, Kraków 1998; B. S t e i n b o r n, O pomocniczej roli rycin niderlandzkich, [w:] Niderlandyzm na Slasku $i$ w krajach ościennych, red. M. Kapustka, A. Kozieł, P. Oszczanowski, Wrocław 2003, s. 54-79. Ta ostatnia zawiera próbę ujęcia statystycznego i systematyki wzorów dla Śląska w latach 1522-1620.

${ }^{19}$ Zwiazki rodzinne Zygmunta III z Cesarstwem przekładały się na kontakty artystyczne z Bawarią na długo przedtem, nim jego córka Anna Katarzyna Konstancja poślubiła Filipa Wilhelma Neuburskiego (1642) - por. Sztuka dworu Wazów w Polsce. Wystawa w Zamku Królewskim na Wawelu, maj-czerwiec 1976. Katalog, red. A. Fischinger, Kraków 1976; J. Z mu $\mathrm{dz}$ i ń s k i, Relacje artystyczne Krakowa z Augsburgiem $w$ dziedzinie zlotnictwa $w$ XVII $w$. Zarys problematyki badawczej, „Rocznik Biblioteki Naukowej PAU i PAN w Krakowie”, XLVIII (2003), s. 57-83. 


\section{Adoration of Virgin Mary Attended by Two St. Johns in Wawel Cathedral Collection Summary}

There is a canvas $(98,5 \times 222,5 \mathrm{~cm})$ in the Wawel Cathedral that is not connected with any existing or historically documented altars inside the church (i1. 1-3). Owing to its shape it has so far been considered to have been a predella, which - taking into account its size and proportions - seems rather unlikely. It may have been the top of the middle part of a retable, possibly in an altar dedicated to the two St. Johns.

The painting presents the Virgin Mary with the Child seated under a canopy, attended by the two Saints, adored by kneeling angels with censers in their hands. A graphic model of the scene has been found; it is an engraving by Jan Sadeler (1550-1600) based on a design by Hans von Aachen (1552-1615), released in Munich in 1589 (il. 4). In Albertina, in Vienna, a working copy of the graphic made by Hans von Aachen has been preserved (il. 5) as well as a composition sketch by the same artist at the Herzog Anton Ulrich-Museum in Braunschweig.

An inscription on the drawing from 1589 reads: POENA ET PROEMIVM; there are also quotations from psalms and a dedication to Phillip Wilhelm (1576-1598), bishop of Regenzburg in 1589, later cardinal (1596), son of a Bavarian ruler Wilhelm V Wittelsbach (1548-1626). The young hierarch got it in the year of his consecration as a bishop. A pendant to it is the plate by Jan Sadeler of 1590, after Peter Candid (1548-1628), which was dedicated to Phillip Wilhelm's younger brother - Ferdinand (1577-1650), later bishop of Cologne. The engraving also shows St. Mary with the Child in the company of St. Stephen and St. Laurence. Both works coincide with the artistic activity of Jan Sadeler and Hans von Achen in Munich, where they were summoned by Wilhelm $V$, and represent strictly planned art created for his court.

Another painted version of Sadeler's engraving was found in a Polish private collection. This is a small, good painting on panel, faithfully reproducing physiognomy and inscriptions known from the prototype (il. 6).

The picture in the Wawel Cathedral, probably painted in Cracow between 1600-1630 and based on the Munich model, is one of the examples of assimilating mannerist engravings from southem Germany in the Cracow environment. Their large influx into Little Poland at the end of the $16^{\text {th }}$ and the beginning of the $17^{\text {th }}$ century may be connected with animated contacts of Sigismund III's court with Bavaria and its artistic centres such as Augsburg, the main purveyor of goldsmith's work for the Polish king's court. 


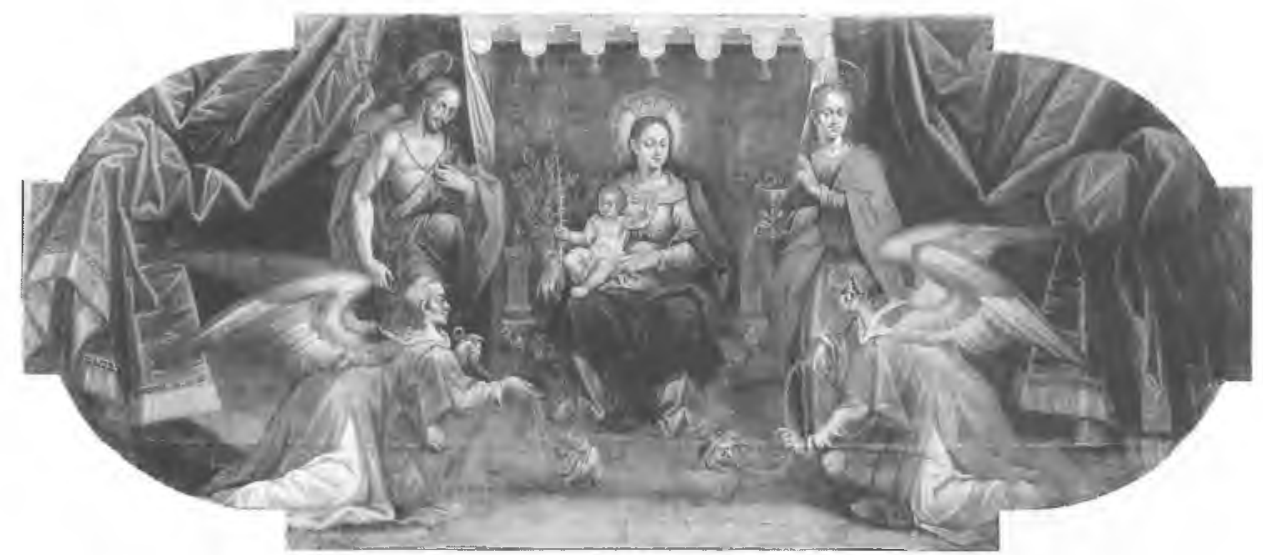

1. Adoracja Matki Boskiej z dwoma Świętymi Janami, Polska, 1. tercja w. XVII. Kraków, katedra na Wawelu (fot. S. Michta).

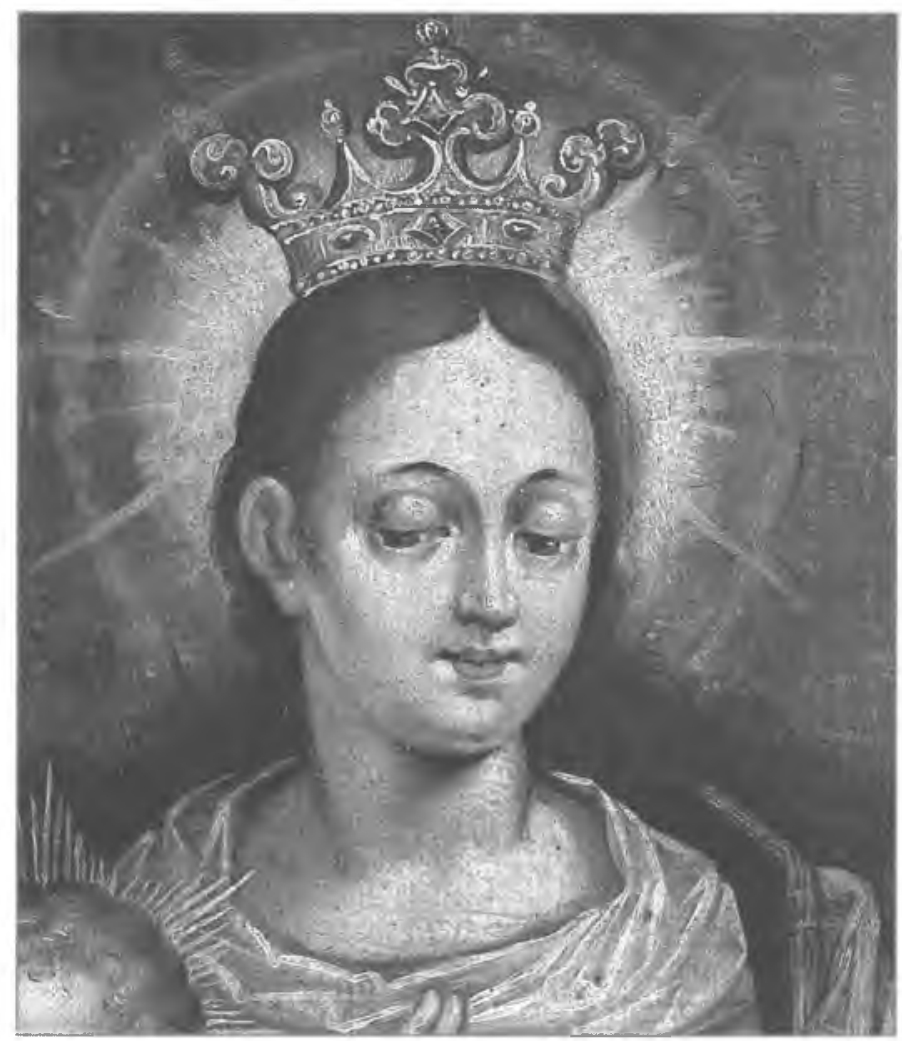

2. Glowa Marii - fragment il. 1. 


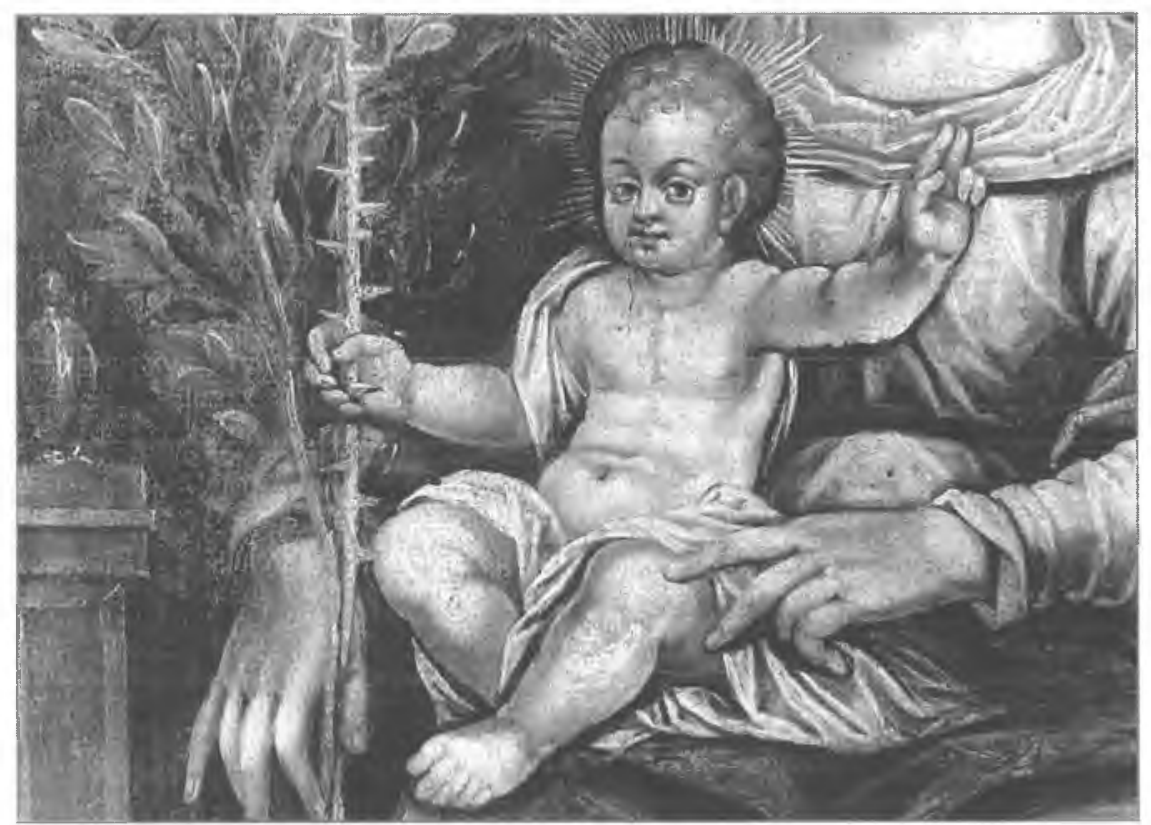

3. Dzieciątko - fragment il. 1.

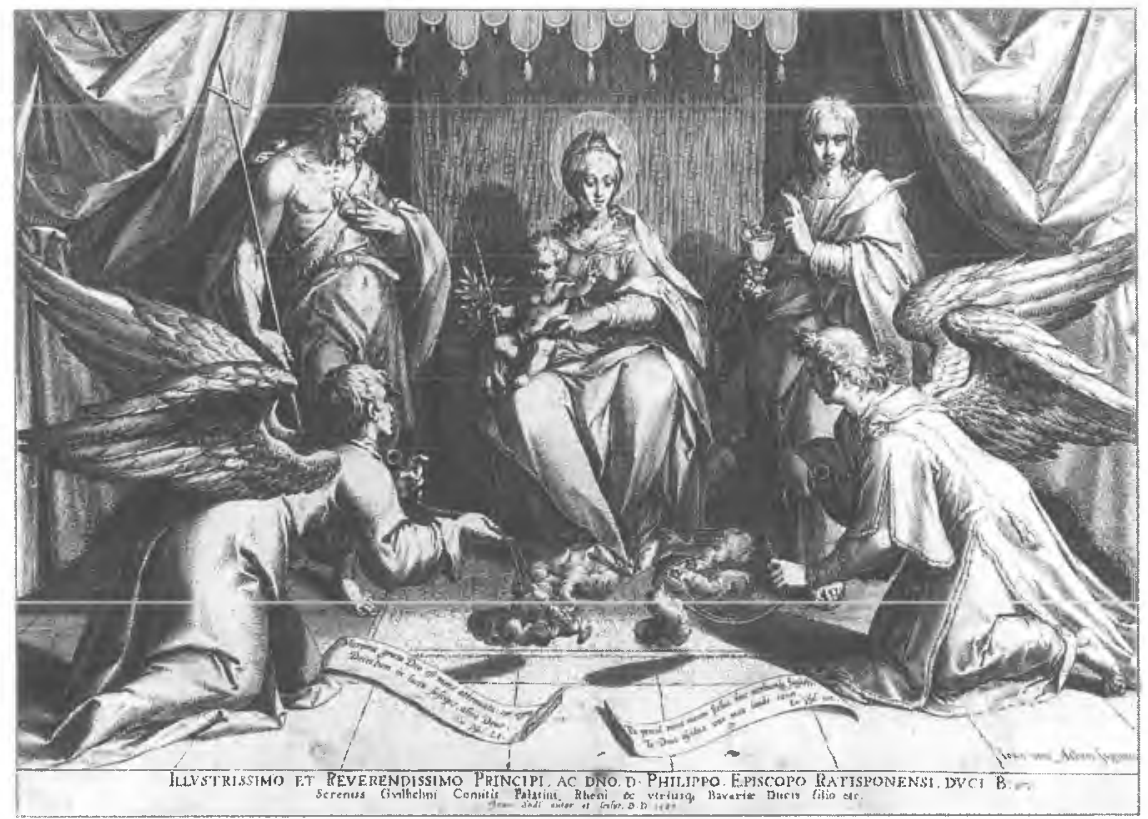

4. Adoracja Matki Boskiej z dwoma Świętymi Janami, Jan Sadeler wg Hansa von Aachen, 1589 (fot. S. Michta). 


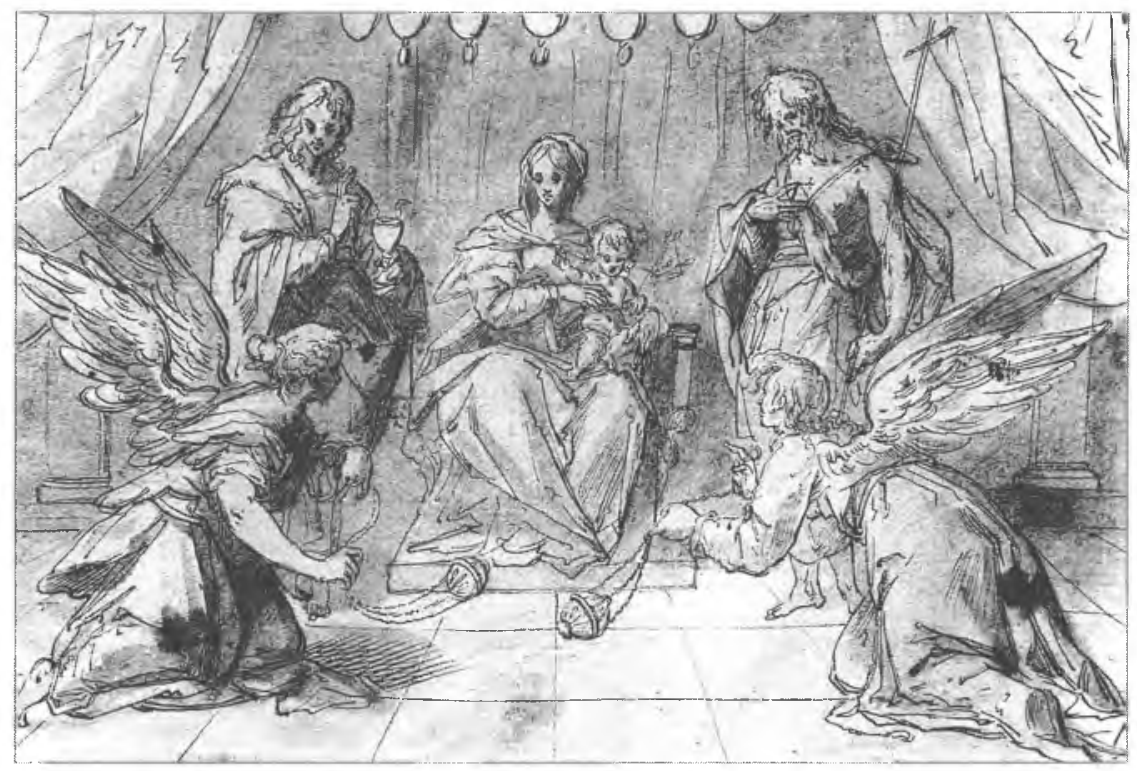

5. Adoracja Matki Boskiej z dwoma Świętymi Janami, Hans von Aachen (fot. S. Michta).

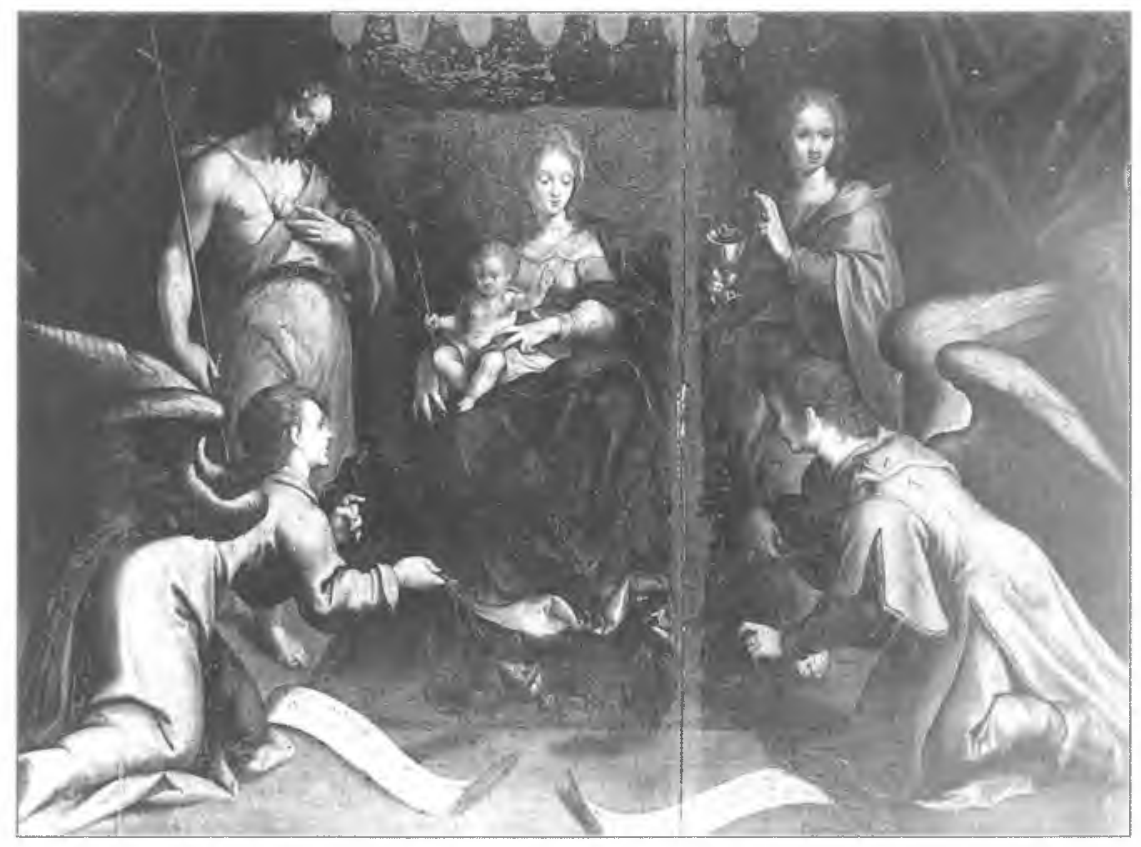

6. Adoracja Matki Boskiej z dwoma Świętymi Janami, 1. tercja w. XVII (?). Zbiory prywatne (fot. J. Kozina). 